\title{
Seasonality and temporal structuration of Alticini community (Coleoptera, Chrysomelidae, Galerucinae) in the Araucaria Forest of Parana, Brazil ${ }^{1}$
}

\author{
Adelita Maria Linzmeier ${ }^{2} \&$ Cibele Stramare Ribeiro-Costa ${ }^{2}$
}

${ }^{1}$ Contribution $n^{\circ} 1738$ of the Departamento de Zoologia, Universidade Federal do Paraná, Brazil.

${ }^{2}$ Laboratório de Sistemática e Bioecologia de Coleoptera (Insecta), Departamento de Zoologia, Universidade Federal do Paraná, Caixa Postal 19020,81531-980 Curitiba-PR, Brazil.CNPq fellowships. alinzmeier@yahoo.com.br; stra@ufpr.br

\begin{abstract}
Seasonality and temporal structuration of Alticini community (Coleoptera, Chrysomelidae, Galerucinae) in the Araucaria Forest of Parana, Brazil. Seasonality was studied for Alticini trapped with malaise over a period of two years in the Vila Velha State Park, Parana, Brazil. Coleoptera, Chrysomelidae and Alticini showed seasonal distribution, with the highest abundance during spring and summer months. The abundance peaks of these groups were not synchronized. Of all environmental variables tested, photoperiod had the larger effect on the distributional patterns of Coleoptera, Chrysomelidae and Alticini. Also, Chrysomelidae and Alticini probably are related to the quality and availability of hostplants. When richness was high there was a greater similarity among seasons of different years. However, when richness was not pronounced, seasons showed more similarity within the same year than between years. The Alticini community was seasonally structured and a possible mechanism underlying this pattern is asymmetric competition. Nevertheless, it is necessary to account for indirect interactions (plant-enemy mediated) to better understand how Alticini community is structured.
\end{abstract}

KEYWORDS. Abundance; community structure; competition; herbivorous; seasonality.

RESUMO. Sazonalidade e estruturação temporal da comunidade de Alticini (Coleoptera, Chrysomelidae, Galerucinae) na Floresta com Araucária do Paraná, Brasil. Foi estudada a sazonalidade de Alticini coletados com armadilha malaise, durante dois anos no Parque Estadual de Vila Velha, Paraná, Brasil. Coleoptera, Chrysomelidae e Alticini apresentaram distribuição sazonal com maior abundância nos meses de primavera-verão, mas os picos de abundância não foram coincidentes. Dentre todas as variáveis ambientais testadas, o fotoperíodo teve maior influência nos padrões de distribuição de Coleoptera, Chrysomelidae e Alticini, sendo que Chrysomelidae e Alticini provavelmente também estão relacionados à disponibilidade e qualidade de suas plantas hospedeiras. Nas estações mais ricas houve maior similaridade entre as estações dos diferentes anos, porém nas estações menos ricas houve maior similaridade dentro do mesmo ano que entre os anos. A comunidade de Alticini mostrou-se sazonalmente estruturada, sendo a competição assimétrica o provável mecanismo atuante. Entretanto, são necessários estudos das interações indiretas (mediadas por plantas-inimigos naturais) para melhor entender como a comunidade de Alticini é estruturada.

PALAVRAS-CHAVE. Abundância; competição; estrutura de comunidade; herbívoros; sazonalidade.

One of the most important characteristics that structures animal communities is the temporal variation in species occurrence (Schoener 1974). The pattern produced by temporal variability is a product of biotic and abiotic factors, and can occur on shorter time scales, such as daily variations, as well as longer scales, in the case of seasonal variations. Among the abiotic variables that influence the seasonal variation, changes in the length of the day throughout the years has proven to be a very good estimate since this is a measure correlated to temperature, humidity, food supply and other factors that affect the development of organisms (Tauber et al. 1986).

Coleoptera, with more than 350,000 species and approximately $40 \%$ of all described insects (Lawrence \& Britton 1991), has a high diversity of food habits. Within Coleoptera, Chrysomelidae is the second richest group, and includes Alticini, a tribe of Galerucinae, with about 8,000 essentially herbivorous species (Jolivet \& Petitpierre 1976, Scherer 1988). Both Chrysomelidae and Alticini are directly related to their host plant phenology, which in turn is also under the influence of climatic seasonality (Marques \& Oliveira 2004, Marques et al. 2004).

Alticini has been the most species-rich and abundant group in Chrysomelidae community studies developed in different regions and with different collecting methods (Farrell \& Erwin 1988, Takizava 1994, Basset \& Samuelson 1996, Novotný et al. 1999, Wagner 1999, Wasowska 2006, Linzmeier et al 2006). Among the studies, only Takizava (1994) evaluated seasonal changes in leaf beetle fauna. Brazilian Alticini was treated only by Linzmeier et al. (2006), however, no information is available on seasonal fluctuation of Brazilian Chrysomelidae and Alticini as a whole.

Given the specific food habit of Alticini, one expects that the community show a distributional pattern synchronized with their host plants. However, it is possible that in addition to the host plants phenology, other biotic factors interact to produce seasonal patterns, such as intra and interspecific competition, the presence of predators, parasitoids, etc. 
Considering the role played by season on host abundance, as well as its role as a factor that structures communities, the goals of the present paper are to verify 1 ) if there is seasonal variation in species composition; 2 ) if this variation is related to taxonomic hierarchies; 3 ) which factors could produce the patterns and, 4) if Alticini community is structured by such temporal variations.

\section{MATERIALAND METHODS}

This survey took place in the Vila Velha State Park (25'13'5,0"S, 50²'26,9'W), in Ponta Grossa, state of Parana, near the Rodovia do Café, BR 376, Km 83, at 880m of altitude, from August 30, 1999 to August 27, 2001.

According to Köppen's classification, the climate type is $\mathrm{Cfb}$, temperate always humid with well defined seasons and cold winters with frost more than five times a year. Rainfall is well distributed throughout the year, the average monthly temperature ranges from $7.4^{\circ} \mathrm{C}$ (July) to $27.2^{\circ} \mathrm{C}$ (January) and annual precipitation from September 1999 to August 2001 averaged $1,637.7 \mathrm{~mm}$.

The Coleoptera were collected in five areas: an edge of grassland-forest, an area of unmanaged araucaria reforestation, and in three successional stages of Araucaria Forest. Detailed information about these areas could be found in Ganho \& Marinoni (2003). In each area a malaise trap was placed (Townes 1972) and the insects was removed weekly from September 1999 to August 2001. The material was deposited in the Coleção de Entomologia Pe. J. S. Moure of the Departamento de Zoologia, Universidade Federal do Paraná.

Temperature, relative humidity of the air and rainfall data used in analysis were obtained from Instituto Agronômico do Paraná (IAPAR) and Instituto Tecnológico SIMEPAR. The Meteorological Station of Vila Velha Park is about $1.5 \mathrm{Km}$ away from the areas. The photoperiod data were obtained from the Anuário Interativo do Observatório Nacional. The Spearman rank correlation was used to test the influence of abiotic factors on Coleoptera, Chrysomelidae and Alticini abundance.

In order to adjust the analysis to the period of collections, which started in September 1999 and finished in August 2001 (two seasonal cycles), the seasons were considered as follows: spring as the months from September to November, summer from December to February, autumn from March to May, and winter from June to August.

To determine if abundance changes seasonally it was used ANOVA with abundance as the response variable and season as predictor. Pos hoc tests were conducted using Tukey test. The normality of the data was previously tested using Kolmogorov-Smirnov analysis. These statistical analyses were carried out with the Statistica 6.0 software application (StatSoft 2001).

In order to study the relationships among the seasons, based on the species occurrence, the Jaccard Coefficient was used followed by a Minimum Spanning Tree analysis calculated on the resultant similarity matrix. These analyses were performed with the NTSYS-pc (Numerical Taxonomy and
Multivariate Analysis System) software application, version 1.50 (Rohlf 1989).

A null model analysis of co-occurrence was carried out to test if competition has played a role in structuring Alticini communities (Gotelli 2000). For this purpose an incidence matrix was constructed for species per season. The analysis of cooccurrence was done calculating the $\mathrm{C}$ score index run under a fixed-fixed algorithm (Gotelli 2000). This simulation was carried out with EcoSim software (EcoSim: Null software models for ecology), version 7.72 (Gotelli \& Entsminger 2006) with 5,000 simulations.

\section{RESULTS ANDDISCUSSION}

During the two-year survey 19,914 Coleoptera were captured, being 10,822 in the first year and 9,092 in the second. From this total, 3,179 individuals belong to Chrysomelidae (1,726 in the first year and 1,453 in the second) and 1,891 to Alticini (978 in the first year and 913 in the second) (Linzmeier et al. 2006).

Coleoptera showed seasonal distribution during both years, with higher abundance in the hottest months (spring-summer) and a reduction in the winter (Fig. 1). At Vila Velha Park, a temperate area, the same abundance pattern has been observed for different insect groups (Marinoni \& Dutra 1991, 1996; Almeida \& Marinoni 2000, Marinoni \& Ganho 2003, Costacurta et al. 2003). According to Scott \& Epstein (1986), temperate insect faunas consist of a seasonal progression of the abundance of different species. The appearance of a species is usually short and occurs during a specific time in the growing season, and usually each species has a specific history stage in which it overwinters.

Regarding the effect of abiotic data on seasonal trends, the highest significant correlations for Coleoptera, were obtained with photoperiod and temperature (Table I; Fig. 2). In temperate regions, changes in species abundance and distribution are determined mainly by these two factors (Wolda 1978a), which are strongly correlated between each other and could even be treated as a single composite variable (Marques et al. 2004).

The distribution pattern of Chrysomelidae is similar to Coleoptera (Fig. 1), showing positive and significant

Table I. Correlation values between Coleoptera, Chrysomelidae and Alticini and the abiotics factors, sampling with malaise trap in the Vila Velha State Park, Ponta Grossa, Parana during September/1999 to August/2001 (N, abundance; S, richness; T. min, minimum temperature; T. mean, average temperature; T. max, maximum temperature; U.R., humidity; Rain. mean, average rainfall).

\begin{tabular}{|c|c|c|c|c|c|c|}
\hline & Photoperiod & T. min & T. mean & T. $\max$ & U.R. & $\begin{array}{l}\text { Rain. } \\
\text { med }\end{array}$ \\
\hline Coleoptera & $0.95 *$ & $0.62 *$ & $0.72 *$ & $0.71 *$ & -0.18 & 0.10 \\
\hline Chrysomelidae & $0.82 *$ & $0.42 *$ & $0.46^{*}$ & $0.45^{*}$ & -0.20 & 0.24 \\
\hline Alticini (N) & $0.65^{*}$ & 0.28 & 0.25 & 0.23 & -0.21 & 0.23 \\
\hline Alticini (S) & $0.63 *$ & 0.16 & 0.18 & 0.20 & -0.22 & 0.13 \\
\hline
\end{tabular}

* Significant correlation $(\mathrm{p}<0.05)$ 

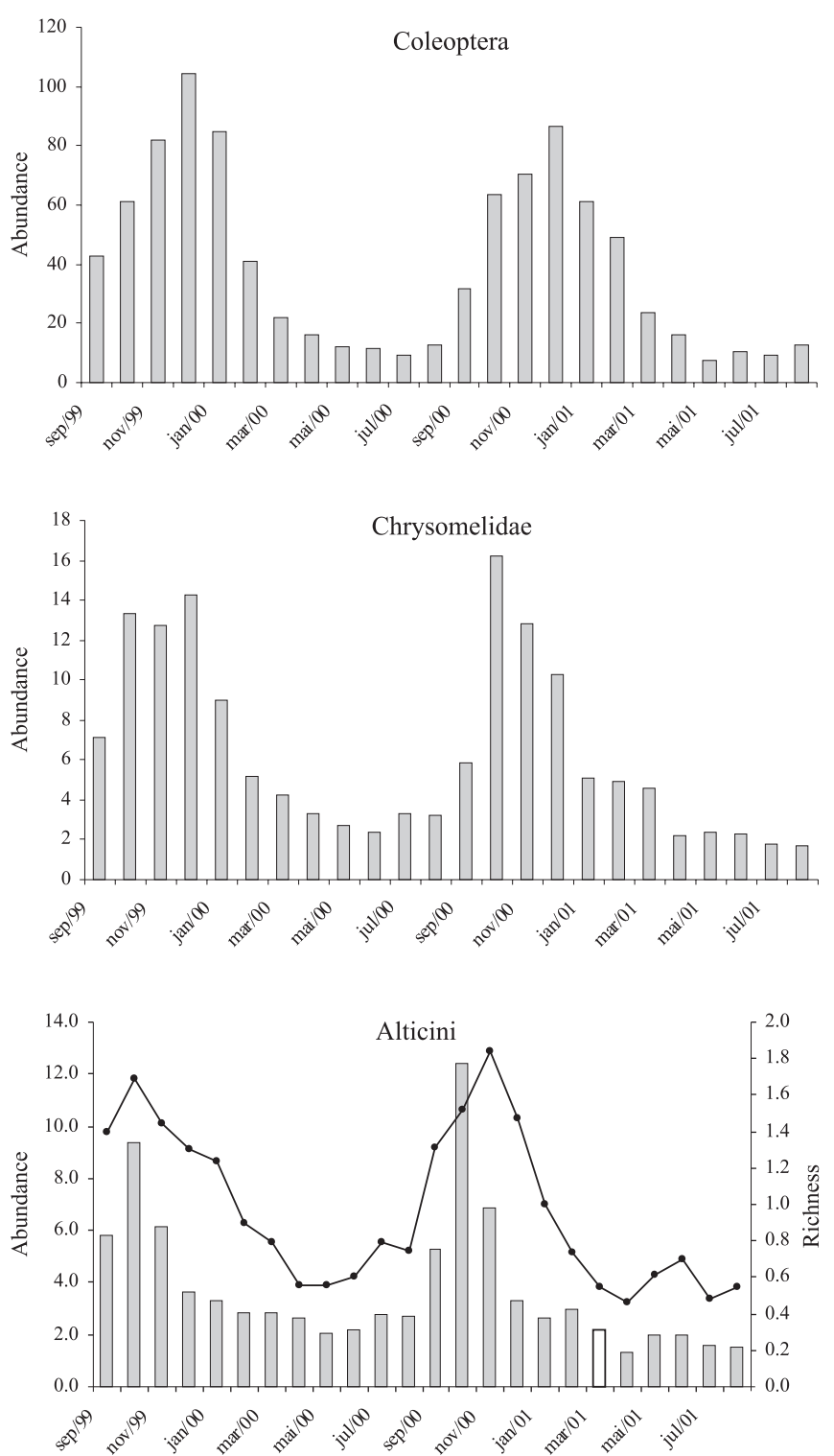

Fig. 1. Seasonality of Coleoptera, Chrysomelidae and Alticini sampling with malaise trap in the Vila Velha State Park, Ponta Grossa, Paraná, during September/1999 to August/2001.

correlations with photoperiod and temperature. However, the first factor showed a higher value (Table I; Fig. 2). The capture peak was in December for the first year and in October for the second, differing from Coleoptera where the peak occurred in December in both years. The higher capture of Chrysomelidae in December during the first year is attributed to the high abundance of Eumolpinae that represented more than double the number of Alticini collected.

Although Coleoptera and Chrysomelidae showed a similar seasonal pattern, the largest captures (more than 50\% of the total annual collection) for Coleoptera were from November to January whereas for Chrysomelidae this happened from October to December. This pattern reflects the food habits of these groups. Chrysomelidae are essentially herbivorous (Jolivet \& Petitpierre 1976) and its occurrence must be mainly during the flushing of the plants, that is, in general, at the beginning of the spring. Coleoptera comprises species with the most varied habits, both herbivorous and not herbivorous. The natural occurrence of Coleoptera predators are indirectly related to leaf production through the increase of the abundance of its prey, the herbivores (Wolda 1978b), which must provoke the displacement of the Coleoptera peak of abundance. The pattern, in which the occurrence peak of Coleoptera families with predator habits comes soon after the corresponding peak for herbivorous families, maintaining the prey-predator relation, as in other animal groups, was also verified by Ganho (2003).

The capture peak of Alticini occurred in October in both years, and was over $50 \%$ of the total collected from September to November. There was significant temporal variation of Alticini community in the seasons $\left(F_{7,16}=3.733 ; \mathrm{p}<0.05\right)$, not found for Coleoptera and Chrysomelidae. The differences were observed only between spring and autumn and between spring and winter of the second year. October of the first year and November of the second were the richest months (Fig. 1). Spring is the time where the plants start germination and flushing of leaves; in the Araucaria Forest the flushing of trees and vines is a seasonal phenomenon that occurs mainly between September and November (Marques et al. 2004). Given the fact that Alticini is predominantly phylophagous (Marinoni
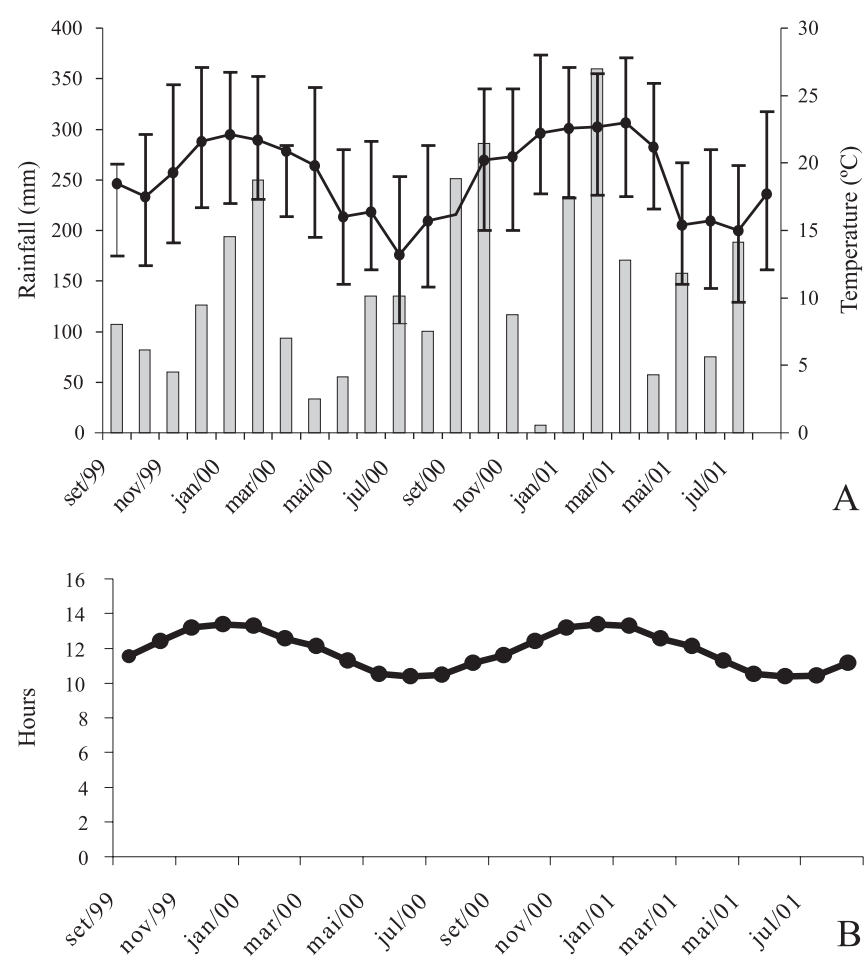

Fig. 2. Abiotic data. A) Monthly values of rainfall $(\mathrm{mm})$ and temperature $\left({ }^{\circ} \mathrm{C}\right)$ gotten through the Meteorological Station of the Vila Velha State Park, Ponta Grossa, Parana, during September/1999 to August/2001. The line represents the average temperature and the bars above and below, the maximum and minimum temperatures, respectively. B) Length of the day in hours of solar light. Source: Anuário Interativo do Observatório Nacional. 
Table II. Alticini species sampling on the seasons by malaise trap in the Vila Velha State Park, Ponta Grossa, Paraná, during September/1999 to August/2001 (1, presence; 0, absence).

\begin{tabular}{|c|c|c|c|c|c|c|c|c|}
\hline \multirow[t]{2}{*}{ Species } & \multicolumn{2}{|c|}{1999} & \multicolumn{4}{|c|}{2000} & \multicolumn{2}{|c|}{2001} \\
\hline & Spring & Summer & Autumn & Winter & Spring & Summer & Autumn & Winter \\
\hline Acallepitrix coracina $($ Boheman, 1859$)$ & 1 & 1 & 0 & 0 & 0 & 0 & 0 & 0 \\
\hline Acanthonycha chloroptera (Germar, 1824) & 1 & 1 & 0 & 0 & 1 & 1 & 0 & 0 \\
\hline Acanthonycha costatipennis Jacoby, 1905 & 1 & 0 & 0 & 0 & 1 & 0 & 0 & 0 \\
\hline Acanthonycha sp. & 0 & 0 & 0 & 0 & 1 & 1 & 1 & 0 \\
\hline Alagoasa coccineloides (Harold, 1847) & 0 & 1 & 0 & 0 & 0 & 0 & 0 & 0 \\
\hline Alagoasa libentina (Germar, 1824) & 1 & 0 & 0 & 0 & 1 & 0 & 0 & 0 \\
\hline Alagoasa parana Samuelson, 1985 & 0 & 1 & 0 & 0 & 0 & 1 & 0 & 0 \\
\hline Alagoasa plaumanni Bechyné, 1955 & 1 & 0 & 0 & 0 & 0 & 0 & 0 & 0 \\
\hline Alagoasa rotundicollis (Jacoby, 1905) & 0 & 1 & 1 & 0 & 1 & 1 & 0 & 0 \\
\hline Alagoasa scissa (Germar, 1824) & 0 & 0 & 0 & 0 & 1 & 0 & 0 & 0 \\
\hline Alagoasa sp.1 & 1 & 0 & 0 & 0 & 1 & 1 & 0 & 0 \\
\hline Alagoasa sp.2 & 0 & 0 & 0 & 0 & 1 & 0 & 0 & 0 \\
\hline Alagoasa vittata (Harold, 1876) & 0 & 1 & 0 & 0 & 0 & 0 & 0 & 0 \\
\hline Altica bohumilae Bechyné, 1954 & 0 & 0 & 0 & 0 & 1 & 0 & 0 & 0 \\
\hline Alticini sp. 4 & 1 & 1 & 1 & 1 & 1 & 1 & 1 & 0 \\
\hline Alticini sp. 21 & 0 & 1 & 0 & 0 & 0 & 0 & 0 & 0 \\
\hline Alticini sp.23 & 0 & 1 & 0 & 0 & 0 & 0 & 0 & 0 \\
\hline Alticini sp.26 & 1 & 0 & 0 & 1 & 0 & 0 & 0 & 0 \\
\hline Alticini sp.35 & 1 & 0 & 0 & 0 & 0 & 0 & 0 & 0 \\
\hline Alticini sp.41 & 1 & 1 & 0 & 0 & 1 & 1 & 0 & 0 \\
\hline Alticini sp.45 & 1 & 1 & 0 & 0 & 1 & 1 & 0 & 0 \\
\hline Alticini sp.47 & 1 & 0 & 0 & 0 & 1 & 0 & 0 & 0 \\
\hline Alticini sp.60 & 0 & 0 & 1 & 0 & 0 & 0 & 0 & 0 \\
\hline Alticini sp.67 & 1 & 0 & 0 & 0 & 0 & 0 & 0 & 0 \\
\hline Alticini sp.75 & 0 & 1 & 0 & 0 & 0 & 0 & 0 & 0 \\
\hline Alticini sp.90 & 0 & 0 & 0 & 1 & 0 & 0 & 0 & 0 \\
\hline Alticini sp.106 & 0 & 0 & 0 & 0 & 1 & 0 & 0 & 0 \\
\hline Alticini sp.110 & 0 & 0 & 0 & 0 & 0 & 1 & 0 & 0 \\
\hline Alticini sp.125 & 0 & 0 & 0 & 0 & 0 & 0 & 0 & 1 \\
\hline Alticini sp.126 & 0 & 1 & 0 & 0 & 0 & 0 & 0 & 0 \\
\hline Alticini sp.127 & 1 & 0 & 0 & 0 & 0 & 0 & 0 & 0 \\
\hline Asphaera auripennis Harold, 1876 & 0 & 0 & 0 & 0 & 0 & 0 & 0 & 1 \\
\hline Asphaera hilaris (Jacoby, 1905) & 0 & 0 & 0 & 0 & 1 & 1 & 1 & 1 \\
\hline Brasilaphthona dilutiventris umbraticeps Bechyné, 1956 & 1 & 0 & 0 & 0 & 0 & 0 & 0 & 0 \\
\hline Brasilaphthona octavia Bechyné, 1955 & 1 & 0 & 0 & 0 & 1 & 0 & 0 & 0 \\
\hline Brasilaphthona sp.1 & 0 & 0 & 0 & 0 & 1 & 1 & 0 & 1 \\
\hline Brasilaphthona sp.2 & 1 & 1 & 0 & 1 & 0 & 0 & 0 & 0 \\
\hline Capraita sp.1 & 1 & 0 & 1 & 0 & 1 & 1 & 0 & 0 \\
\hline Capraita sp.2 & 0 & 1 & 0 & 0 & 1 & 1 & 0 & 0 \\
\hline Chaetocnema braziliensis Baly, 1877 & 0 & 0 & 0 & 0 & 0 & 0 & 0 & 1 \\
\hline Cornulactica jacobyi Bechyné, 1955 & 0 & 0 & 0 & 1 & 0 & 0 & 0 & 0 \\
\hline Coroicona sp. & 0 & 1 & 0 & 0 & 1 & 1 & 0 & 0 \\
\hline Dinaltica gigia Bechyné, 1956 & 1 & 1 & 1 & 1 & 1 & 1 & 1 & 1 \\
\hline Disonycha conjuncta (Germar, 1824) & 1 & 0 & 0 & 0 & 0 & 0 & 0 & 0 \\
\hline Dysonycha plaumanni C. Lima, 1954 & 0 & 1 & 0 & 0 & 0 & 0 & 0 & 0 \\
\hline Epitrix sp.1 & 0 & 1 & 0 & 0 & 0 & 1 & 0 & 0 \\
\hline Epitrix sp. 2 & 0 & 1 & 0 & 0 & 0 & 0 & 0 & 0 \\
\hline Genaphthona yasmina Bechyné, 1955 & 1 & 1 & 1 & 1 & 0 & 0 & 0 & 1 \\
\hline Heikertingerella bimaculata (Baly, 1877) & 1 & 1 & 0 & 1 & 1 & 0 & 1 & 1 \\
\hline Heikertingerella ferruginea Duvivier, 1889 & 1 & 1 & 1 & 1 & 1 & 1 & 1 & 0 \\
\hline Heikertingerella sp.1 & 1 & 1 & 1 & 1 & 0 & 0 & 1 & 1 \\
\hline Heikertingerella sp.2 & 0 & 0 & 0 & 1 & 1 & 0 & 0 & 1 \\
\hline Heikertingerella sp.3 & 0 & 0 & 0 & 0 & 1 & 1 & 0 & 0 \\
\hline Heikertingerella sp.4 & 0 & 0 & 0 & 0 & 1 & 0 & 0 & 0 \\
\hline Heikertingerella sp.5 & 1 & 1 & 1 & 1 & 1 & 1 & 1 & 0 \\
\hline Heikertingerella sp.6 & 0 & 0 & 0 & 0 & 1 & 0 & 0 & 0 \\
\hline Heikertingerella sp.7 & 0 & 0 & 0 & 1 & 0 & 1 & 0 & 0 \\
\hline
\end{tabular}


Table II. Cont.

\begin{tabular}{|c|c|c|c|c|c|c|c|c|}
\hline \multirow[t]{2}{*}{ Species } & \multicolumn{2}{|c|}{1999} & \multicolumn{4}{|c|}{2000} & \multicolumn{2}{|c|}{2001} \\
\hline & Spring & Summer & Autumn & Winter & Spring & Summer & Autumn & Winter \\
\hline Heikertingerella sp. 8 & 1 & 1 & 1 & 1 & 1 & 1 & 1 & 0 \\
\hline Heikertingerella sp.9 & 1 & 0 & 0 & 1 & 0 & 0 & 0 & 0 \\
\hline Hypolampsis ambiguus (Clark, 1860) & 0 & 1 & 0 & 0 & 0 & 1 & 1 & 0 \\
\hline Hypolampsis fragilis (Clark, 1860) & 1 & 0 & 0 & 0 & 1 & 0 & 0 & 0 \\
\hline Hypolampsis nigripes (Clark, 1860) & 0 & 0 & 0 & 0 & 1 & 0 & 0 & 0 \\
\hline Hypolampsis sp.1 & 1 & 1 & 1 & 1 & 1 & 1 & 1 & 1 \\
\hline Hypolampsis sp.2 & 1 & 0 & 0 & 0 & 1 & 0 & 0 & 0 \\
\hline Hypolampsis sp.3 & 1 & 0 & 0 & 0 & 1 & 0 & 0 & 0 \\
\hline Hypolampsis sp.4 & 1 & 0 & 0 & 1 & 0 & 0 & 0 & 1 \\
\hline Hypolampsis sp.5 & 1 & 0 & 0 & 0 & 0 & 0 & 0 & 0 \\
\hline Longitarsus sp.1 & 1 & 1 & 0 & 1 & 1 & 0 & 1 & 1 \\
\hline Longitarsus sp. 2 & 0 & 0 & 0 & 0 & 1 & 0 & 0 & 0 \\
\hline Longitarsus sp. 3 & 1 & 0 & 0 & 0 & 0 & 0 & 0 & 0 \\
\hline Monomacra yena Bechyné, 1957 & 1 & 1 & 1 & 1 & 0 & 0 & 0 & 0 \\
\hline Monoplatus ocularis Bechyné, 1955 & 1 & 1 & 1 & 1 & 1 & 1 & 1 & 1 \\
\hline Neodiphaulaca itapiranga (Bechyné, 1957) & 1 & 0 & 0 & 0 & 1 & 0 & 0 & 0 \\
\hline Neothona prima Bechyné, 1955 & 1 & 1 & 0 & 0 & 1 & 0 & 0 & 0 \\
\hline Omophoita equestris (Fabricius, 1787) & 0 & 1 & 0 & 0 & 0 & 0 & 0 & 0 \\
\hline Omophoita magniguttis (Bechyné,1955) & 1 & 0 & 0 & 0 & 0 & 0 & 0 & 0 \\
\hline Omophoita octoguttata (Fabricius, 1875) & 1 & 1 & 0 & 1 & 1 & 1 & 1 & 1 \\
\hline Omophoita sexnotata Harold, 1876 & 0 & 1 & 0 & 0 & 1 & 1 & 0 & 0 \\
\hline Paranaita bilimbata (Baly, 1859) & 0 & 0 & 0 & 1 & 0 & 1 & 0 & 0 \\
\hline Paranaita crotchi (Blackwelder, 1946) & 0 & 0 & 1 & 0 & 0 & 1 & 0 & 0 \\
\hline Phyllotrupes violaceomaculatus (Bechyné, 1958) & 1 & 1 & 0 & 1 & 1 & 0 & 0 & 0 \\
\hline Physimerus sp. & 0 & 0 & 0 & 0 & 1 & 0 & 0 & 0 \\
\hline Pyxidaltica variegata (Jacoby, 1880) & 0 & 0 & 0 & 0 & 1 & 0 & 0 & 0 \\
\hline Rhinotmetus diversipes (Bechyné, 1956) & 0 & 1 & 0 & 0 & 1 & 1 & 0 & 0 \\
\hline Rhinotmetus sp.1 & 1 & 0 & 0 & 0 & 1 & 0 & 0 & 0 \\
\hline Rhinotmetus sp.2 & 1 & 0 & 0 & 0 & 0 & 0 & 0 & 0 \\
\hline Rhinotmetus sp.3 & 0 & 0 & 0 & 1 & 0 & 0 & 0 & 0 \\
\hline Stegnea inflatipes (Bechyné, 1955) & 1 & 1 & 0 & 0 & 1 & 1 & 0 & 0 \\
\hline Syphraea multiimpressa Bechyné, 1955 & 0 & 0 & 0 & 0 & 0 & 1 & 0 & 0 \\
\hline Syphraea olga Bechyné, 1956 & 1 & 1 & 1 & 1 & 1 & 1 & 1 & 1 \\
\hline Syphraea plaumanni Bechyné, 1955 & 0 & 0 & 0 & 1 & 0 & 1 & 1 & 1 \\
\hline Syphraea sp.1 & 0 & 1 & 1 & 1 & 1 & 1 & 1 & 1 \\
\hline Syphraea sp.2 & 0 & 1 & 1 & 1 & 0 & 1 & 0 & 0 \\
\hline Syphraea sp.3 & 1 & 0 & 0 & 0 & 0 & 0 & 0 & 0 \\
\hline Systena tenuis Bechyné, 1954 & 0 & 1 & 0 & 0 & 1 & 1 & 0 & 0 \\
\hline Systena $\mathrm{sp}$. & 0 & 0 & 0 & 0 & 0 & 1 & 0 & 0 \\
\hline Trichaltica elegantula Baly, 1876 & 1 & 1 & 1 & 0 & 1 & 1 & 0 & 0 \\
\hline Trichaltica micros Bechyné, 1954 & 1 & 1 & 0 & 0 & 1 & 0 & 0 & 0 \\
\hline Trichaltica sp. & 0 & 0 & 0 & 0 & 0 & 1 & 0 & 0 \\
\hline Walterianella argentinensis (Jacoby, 1905) & 1 & 0 & 0 & 0 & 1 & 0 & 0 & 0 \\
\hline Walterianella interruptovittata (Jacoby, 1905) & 0 & 0 & 1 & 0 & 1 & 0 & 0 & 0 \\
\hline Walterianella sp. & 0 & 0 & 0 & 0 & 0 & 1 & 0 & 0 \\
\hline Wanderbiltiana festiva (Germar, 1824) & 0 & 1 & 1 & 0 & 1 & 1 & 0 & 0 \\
\hline Wanderbiltiana novoteutoniensis Bechyné, 1955 & 0 & 0 & 1 & 0 & 0 & 0 & 0 & 0 \\
\hline Wanderbiltiana sejuncta (Harold, 1880) & 1 & 1 & 0 & 0 & 1 & 1 & 1 & 0 \\
\hline Wanderbiltiana sp. & 0 & 0 & 1 & 0 & 1 & 0 & 0 & 0 \\
\hline
\end{tabular}

et al. 2001) it is possible that the largest abundance is related when the leaves are tender and have high nutritional value. Many herbivorous insects reach a better development and high fecundity when they feed on young leaves, compared to those that feed on mature ones of the same plant. Mature leaves tend to lose water and proteins and to accumulate tannins (Feeny \& Bostock 1968, Stamp \& Bowers 1990). Tannins and resins are digestibility-reducers that act decreasing the absorption of nutrients for herbivorous insects (Schoonhoven et al. 1998).

As Alticini is the most abundant group of Chrysomelidae, its seasonality largely mirrors what is seen for the family. Thus, 


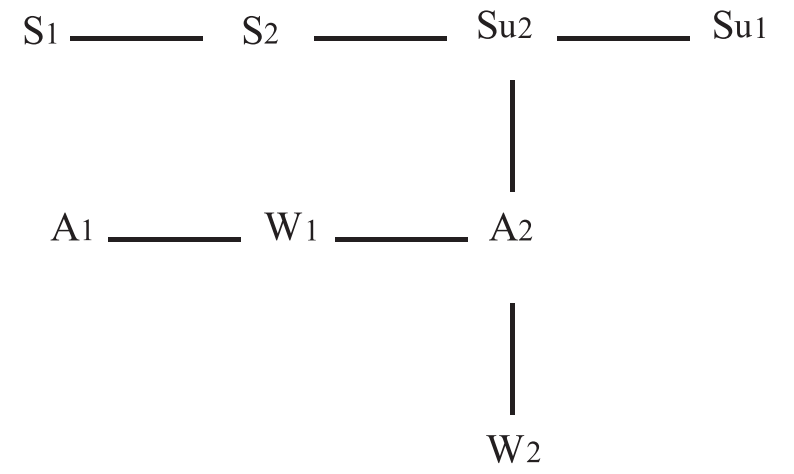

Fig. 3. Minimum Spanning Tree. Coefficient of Jaccard. Presence/ absence of Alticini species in the seasons, sampling with malaise trap during September/1999 to August/2001 in the Vila Velha State Park, Ponta Grossa, Paraná. (S1: spring of the first year; S2: spring of the second year; Su1: summer of the first year; Su2: summer of the second year; A1: autumn of the first year; A2: autumn of the second year; W1: winter of the first year; W2: winter of the second year).

the peak of Chrysomelidae and Alticini coincided in the second year of the sampling. In the first year, no coincidence was observed due to the great abundance of Eumolpinae in December.

Alticini, in contrast with Coleoptera and Chrysomelidae, has positive and significant correlation only with photoperiod (Table I; Fig. 2). This variable is one of the factors that have most influenced plant phenology in the Araucaria Forest (Marques et al. 2004). Moreover, in contrast with the other seasonal factors, the photoperiod is always similar at a fixed time of the year and location. This characteristic, at least for insects of temperate areas, can act as a stimulus indicating, for example, the end of the diapause period (Leather et al. 1993).

During the two-year sampling period, 106 species of Alticini were collected (Linzmeier et al. 2006). It was observed that $29.2 \%$ occurred exclusively in spring, $15.1 \%$ in summer, $5.7 \%$ in winter and $1.9 \%$ in autumn. Only four species $(3.8 \%)$ occurred in all seasons of the two-year sampling period, Dinaltica gigia Bechyné, 1956, Monoplatus ocularis Bechyné, 1955, Syphraea olga Bechyné, 1956 and Hypolampsis sp.1 (Table II).

The higher richness was observed in spring and summer. For these seasons, species composition displayed greatest similarity when comparing the same season in different years (Fig. 3). On the other hand, the lower richness was observed in autumn and winter where the greatest similarity was observed within a given year. Indeed, species registered in the autumn or winter of the first year will not always be collected in the next year (Fig. 3; Table II). Species composition is also correlated with photoperiod (Table I) and is still influenced by other biotic factors such as the availability and quality of the food that is also under the influence of the photoperiod.

The null model results indicated that the seasons play an important role in determining co-occurrence patterns of the Alticini community of Vila Velha Park $\left(\mathrm{C}_{\mathrm{obs}}=1.42 ; \mathrm{C}_{\mathrm{cal}}=1.36\right.$; $\mathrm{p}<0.01)$. Interspecific competition is one of the main causes of structuration of animal communities (Schluter \& Riccklefs 1993), and possibly play an important role in Alticini community. However, their importance is a highly controversial and unresolved issue for community ecology in general, and for herbivorous insects in particular (Kaplan \& Denno 2007). For these insects, asymmetrical competition occurs with higher frequency (Lawton \& Hassell 1981, Denno et al. 1995, Speight et al. 1999) and is one of the few generalities that remain consistent across trophic levels and taxonomic groups. Although, the fact that herbivorous insects typically consume a small fraction of potentially available plant foliage point out that quantity of available resource is not limiting for them. However, even small amounts of damage can induce systemic defenses with important ecological effects (Denno \& Kaplan 2007). So, the indirect interactions, via plants and enemies, can show a vast majority of evidence for interspecific herbivore interactions. Therefore, a new paradigm that also account for indirect interactions (plant-enemy mediated) is required to describe how interspecific competition contributes to the organization of phytophagous insect communities (Kaplan \& Denno 2007).

\section{CONCLUSION}

Chrysomelidae and Alticini communities showed to be seasonally distributed, occurring mainly in spring-summer, during the months when the photoperiod, the parameter that had the most influence on the seasonality of these insects and their host plants, are longer. In those richest months, probably the competition is more intense, because there are more co-occurring species due to availability and quality of host plants. Early-season exploitation of hosts creates a condition in which initial Alticini colonizers may affect subsequent species. Thus, differences in the phenology of Alticini on plants in seasonal environments could promote asymmetric competition. Nevertheless, it is necessary to account for indirect interactions (plant-enemy mediated) to better understand how Alticini community is structured.

Acknowledgments. We would like to thank to Dr. Renato Contin Marinoni (Universidade Federal do Paraná-UFPR) for the discussions and material provided, to Dr. Maurício Osvaldo Moura (Universidade do Centro-Oeste - UNICENTRO) for his valuable suggestions on this manuscript and to the Conselho Nacional de Desenvolvimento Científico e Tecnológico $(\mathrm{CNPq})$, for providing scholarships to the authors.

\section{REFERENCES}

Almeida, G. L. de \& L. Marinoni. 2000. Abundância e sazonalidade das espécies de Leptoceridae (Insecta, Trichoptera) capturadas com armadilha luminosa no Estado do Paraná, Brasil. Revista Brasileira de Zoologia 17: 347-359.

Basset, Y. \& G. A. Samuelson. 1996. Ecological characteristics of an arboreal community of Chrysomelidae in Papua New Guinea, p. 243-262. In: P. H. A. Jolivet \& M. L. Cox (eds). Chrysomelidae Biology: Ecological Studies. Amsterdam, Academic Publishing, $465 \mathrm{p}$. 
Costacurta, N. C.; R. C. Marinoni \& C. J. B. Carvalho. 2003. Fauna de Muscidae (Diptera) em três localidades do Estado do Paraná, Brasil, capturada por armadilha malaise. Revista Brasileira de Entomologia 47: 389-397.

Denno, R. F.; M. S. McClure \& J. R. Ott. 1995. Interspecific interactions in phytophagous insects: competition reexamined and resurrected. Annual Review of Entomology 40: 297-331.

Denno, R. F. \& I. Kaplan. 2007. Plant-mediated interactions in herbivorous insects: mechanisms, symmetry, and challenging the paradigms of competition past, p. 19-50. In: T. Ohgushi, T. P. Craig \& P. W. Price (eds). Ecological Communities: plant mediation in indirect interaction webs. London, Cambridge University Press. $444 \mathrm{p}$.

Farrell, B. D. \& T. L. Erwin. 1988. Leaf-beetle community structure in an amazonian rainforest canopy, p. 73-90. In: P. Jolivet, E. Petitpierre \& T. Hsiao (eds). Biology of Chrysomelidae. Kluwer Academic, Dordrecht, 608 p.

Feeny, P. P. \& H. Bostock. 1968. Seasonal changes in the tannin content of oak leaves. Phytochemistry 7: 871-880.

Ganho, N. G. 2003. Aspectos ecológicos da fauna de Coleoptera capturada no Parque Estadual de Vila Velha, Ponta Grossa, Paraná, Brasil, em áreas com diferentes condições florísticas. Tese de Doutorado, Universidade Federal do Paraná, Brasil.

Ganho, N. G. \& R. C. Marinoni. 2003. Fauna de Coleoptera no Parque Estadual de Vila Velha, Ponta Grossa, Paraná, Brasil. Abundância e riqueza das famílias capturadas através de armadilhas malaise. Revista Brasileira de Zoologia 20: 727-736.

Gotelli, N. J. 2000. Null model analysis of species co-ocurrence patterns. Ecology 81: 2606-2621.

Gotelli, N. J. \& G. L. Entsminger. 2006. EcoSim: Null models software for ecology. Version 7.72 Acquired Intelligence Inc. \& Kesey-Bear. Jericho, VT 05465. http://garyentsminger.com/ ecosim.htm. Accessed in 10/09/2006.

Jolivet, P. \& E. Petitpierre. 1976. Selection trophique et évolution chromosomique chez les Chrysomelinae (Coleoptera: Chrysomelidae). Acta Zoologica et Pathologica Antverpiensia 66: $59-90$

Kaplan, I. \& R. F. Denno. 2007. Interspecific interactions in phytophagous insects revisited: a quantitative assessment of competition theory. Ecology Letters 10: 977-994.

Lawrence, J. F. \& E. B. Britton. 1991. Coleoptera (Beetles), p. $543-$ 683. In: CSIRO Division of Entomology (ed.) The Insects of Australia. Carlton, Melbourne University Press, 2ed., v.2, 543 p.

Lawton, J. H. \& M. P. Hassell. 1981. Asymetrical competition in insects. Nature 289: 793-795.

Leather, S. R.; K. F. A. Walters \& J. S. Bale. 1993. The Ecology of Insect Overwintering. Cambridge, $255 \mathrm{p}$.

Linzmeier, A. M.; C. S. Ribeiro-Costa \& R. C. Marinoni. 2006. Fauna de Alticini (Newman) (Coleoptera, Chrysomelidae, Galerucinae) em diferentes estágios sucessionais na Floresta com Araucária do Paraná, Brasil: diversidade e estimativa de riqueza de espécies. Revista Brasileira de Entomologia 50: 101-109.

Marinoni, R. C. \& R. R. C. Dutra. 1991. Levantamento da fauna entomológica no Estado do Paraná. I. Introdução. Situação climática e florística de oito pontos de coleta. Dados faunísticos de agosto de 1986 a julho de 1987. Revista Brasileira de Zoologia 8: 31-73.

Marinoni, R. C. \& R. R. C. Dutra. 1996. Levantamento da fauna entomológica no Estado do Paraná. II. Ctenuchidae (Lepidoptera). Revista Brasileira de Zoologia 13: 435-461.

Marinoni, R. C. \& N. G. Ganho. 2003. Sazonalidade de Nyssodrysina lignaria (Bates) (Coleoptera, Cerambycidae, Lamiinae), no Estado do Paraná, Brasil. Revista Brasileira de Zoologia 20: 141-152.

Marinoni, R. C.; N. G. Ganho; M. L. Monné \& J. R. M. Mermudes. 2001. Hábitos alimentares em Coleoptera (Insecta). Ribeirão Preto, Holos, 63 p.

Marques, M. C. M. \& P. E. A. M. Oliveira. 2004. Fenologia de espécies do dossel e do sub-bosque de duas Florestas de Restinga na ilha do Mel, sul do Brasil. Revista Brasileira de Botânica 27: 713-723.

Marques, M. C. M.; J. J. Ropper \& A. P. B. Salvalaggio. 2004. Phenological patterns among plant life-forms in a subtropical forest in southern Brazil. Plant Ecology 173: 203-213.

Novotný, V.; Y. Basset; G. A. Samuelson \& S. E. Miller. 1999. Host use by chrysomelid beetles feeding on Moraceae and Euphorbiaceae in New Guinea, p. 545-555. In: M. L. Cox. Advances in Chrysomelidae Biology 1. Backhuys Publishers, Leiden, The Netherlands, $671 \mathrm{p}$.

Rohlf, F. J. 1989. NTSYS-PC. Numerical Taxonomy and Multivariate Analysis System. New York, Exeter Publ. Ltd, $187 \mathrm{p}$.

Scherer, G. 1988. The origins of the Alticinae, p.115-130. In: P. Jolivet, E. Petitpierre \& T. Hsiao (eds.). Biology of Chrysomelidae. Kluwer Academic, Dordrecht, 608 p.

Schluter, D. \& R. E. Ricklefs. 1993. Species diversity: an introduction to the problem, p. 1-10. In: R. E. Ricklefs \& D. Schluter (eds). Species diversity in ecological communities: historical and geographical perspectives. Chicago, University of Chicago Press, 414 p.

Schoener, T. W. 1974. Resource partitioning in ecological communities. Science 185: 27-39.

Schoonhoven, L. M.; T. Jermy \& J. J. A. van Loon. 1998. Insectplant biology. From physiology to evolution. London, Chapman \& Hall, 409 p.

Scott, J. A. \& M. E. Epstein. 1986. Factors affecting phenology in a temperate insect community. The American Midland Naturalist 117: $103-118$.

Speight, M. R.; M. D. Hunter \& A. D. Watt. 1999. Ecology of insects, concepts and applications. Oxford, Blackwell Science, $350 \mathrm{p}$.

Stamp, N. E. \& M. D. Bowers. 1990. Phenology of nutritional differences between new and mature leaves and its effect on caterpillar growth. Ecological Entomology 15: 447-454.

Takizawa, H. 1994. Seasonal changes in leaf beetle fauna of a warm temperate lowland in Japan, p. 511-525. In: P. H. Jolivet, M. L. Cox \& E. Petitpierre (eds). Novel aspects of the biology of Chrysomelidae. Kluwer Academic Publishers, Netherlands, 582p.

Tauber, N. J.; C. A. Tauber \& S. Masaki. 1986. Seasonal adaptations of insects. New York, Oxford University Press, 411 p.

Townes, H. 1972. A light-weight malaise trap. Entomological News 83: 239-247.

Wagner, T. 1999. Arboreal chrysomelid community structure and faunal overlap between different types of forests in Central África, p. 247-270. In: M. L. Cox (ed.). Advances in Chrysomelidae Biology 1. Backhuys Publishers, Leiden, The Netherlands, 671 p. Wasowska, M. 2006. Chrysomelid communities (Chrysomelidae, Coleoptera) of xerothermic grasslands (Inuletum ensifoliae) in the Wyzyna Miechowska Uplands (Central Poland). Biologia, Bratislava 61: $565-572$.

Wolda, H. 1978a. Fluctuations in abundance of tropical insects. The American Naturalist 112: 1017-1045.

Wolda, H. 1978b. Seasonal fluctuations in rainfall, food and abundance of tropical insects. Journal of Animal Ecology 47: 369-381. 